\title{
Group B streptococci in women fitted with intrauterine devices
}

\author{
R. G. MitChell, J. GUILlebAUD, AND D. G. DAY \\ From the Department of Pathology and Nuffield Department of Obstetrics and Gynaecology, Churchill \\ Hospital, Headington, Oxford, UK
}

SUMMARY A survey was made of group B streptococcal carriage at various sites in 100 women attending a clinic for the insertion of an intrauterine contraceptive device (IUD). Twenty-three women carried streptococci at one or more sites at the preinsertion visit, the vaginal carriage rate being $16 \%$. Six months after insertion changes in carrier status were noted and there was evidence of a change of strain in four patients. Twenty-nine women were carriers at one or more sites at some stage of the study. There was no evidence that symptoms attributable to infection in patients fitted with an IUD were caused by group B streptococci.

The importance of group B streptococci as a cause of serious perinatal infections is now well recognised (Hood et al., 1961; Eickhoff et al., 1964; Reid, 1975). In consequence, several studies have been made of the carriage rates for this organism among antenatal patients, neonates, and hospital personnel (Franciosi et al., 1973; Baker and Barrett, 1973) but comparatively few of the rate for non-pregnant women outside hospital. Topley and Wilson (1975) stated that group B streptococci are present in the vagina of $3-5 \%$ of normal women. Butter and de Moor (1967) found an overall human carrier rate of $10 \%$ in the vagina, rectum, and throat. Franciosi et al. (1973) found a vaginal carriage rate of $11.6 \%$ in non-pregnant women outside hospital. Finch et al. (1976) found a vaginal carriage rate of $17 \%$ among 123 women attending family planning clinics. Baker et al. (1976) found a rate of $18 \%$ among 460 college students in a health service.

An investigation into the effect of IUDs on the genital flora gave us the opportunity to study group B streptococcal carriage in 100 women attending a family planning clinic.

\section{Patients and methods}

None of the patients had received chemotherapy within the month preceding their first attendance. All were in the second week of the menstrual cycle, the appropriate time for IUD insertion.

Received for publication 21 April 1977
Using a sterile speculum swabs were taken of the cervical mucus and the endocervical canal and placed in Stuart's transport medium. A low vaginal swab was taken at introital level. Swabs moistened in sterile saline were taken of the urethra, anorectal region, nose, and throat. All swabs were obtained by the same doctor and processed in the laboratory within an hour, usually within minutes, of collection.

Further endocervical and low vaginal swabs were taken six months after insertion of the device and subsequently whenever an opportunity arose.

Endocervical swabs were plated on horse blood agar (Columbia base) and incubated aerobically and anaerobically with additional $\mathrm{CO}_{2}$ for up to 48 hours and also on MacConkey agar, Oxoid CM 7B. Swabs from other sites were plated on horse blood agar and on blood agar containing crystal violet $2 \mathrm{mg} / \mathrm{l}$ and nalidixic acid $15 \mathrm{mg} / \mathrm{l}$ and incubated anaerobically with $\mathrm{CO}_{2}$ for 48 hours. No fluid enrichment methods were used.

Colonies selected by their general appearance, pigmentation, and typical haemolysis (Braunstein et al., 1969; Fallon, 1974) were subcultured and Lancefield-grouped by the formamide method. Sensitivities to antibiotics were determined by the disc method on Mueller-Hinton agar, including a tetracycline $25 \mu \mathrm{g}$ disc. Serotypes of group B streptococci were determined by the gel-slide method as used by the Streptococcus Reference Laboratory, Colindale, which provided antisera to types $\mathrm{Ia}, \mathrm{Ib}$, II, and III. Acid extraction was carried out with $0.2 \mathrm{~N} \mathrm{HCl}$ at $50^{\circ} \mathrm{C}$ for two hours and results were read at 24 and 48 hours. 


\section{Results}

The isolation rates of group B streptococci in 100 normal women at their first (preinsertion) visit are shown in Table 1. Vaginal swabs (endocervical or introital swabs, or both) grew streptococci from 16 women and 23 were carrying streptococci at one or more sites sampled. Six months after insertion eight women had acquired vaginal strains and six were no longer vaginal carriers (Table 2). The losses could not be attributed to recent chemotherapy. The cumulative vaginal carriage rate was $24 \%$; $29 \%$ were carriers at some stage at one or more sites. In $30 \%$ of paired genital swabs group B streptococci were isolated from the introital area but not from the endocervix.

Strains isolated from different sites in individual women were, with one exception, uniformly sensitive or resistant to tetracycline throughout the period of study. Thirteen yielded tetracycline-sensitive strains and 14 yielded resistant strains. These results led us to expect that the women would in general retain the same serotype throughout, but this proved difficult to demonstrate since in only 14 out of 29 were all the serotypes confidently established. Ten women yielded non-typable strains at some stage. Some strains gave mixed serotyping reactions such as II/III and Ia/III and results were sometimes variable when repeatedly testing individual strains. There was good evidence of a change of strain in four women (Table 3). Strains which gave anomalous results in serotyping were examined by the Streptococcus Reference Laboratory, which substantially confirmed our own findings.

\section{SYMPTOMATOLOGY}

Of the four women who acquired group B streptococci in the vagina after IUD insertion three complained of vaginal discharge and one of heavy periods. The only serious symptoms were encoun-
Table 1 Carriage of group B streptococci at various sites in 100 normal women before insertion of IUD

\begin{tabular}{llll}
\hline Site & $\begin{array}{l}\text { No. of } \\
\text { women }\end{array}$ & $\begin{array}{l}\text { Overall carriage } \\
\text { rates }(\%)\end{array}$ \\
\hline Vagina only & 1 & Vagina & 16 \\
Urethra only & 1 & Urethra & 15 \\
Rectum only & 5 & Rectum & 19 \\
Vagina + urethra & 2 & Nose & 1 \\
Vagina + rectum & 2 & Throat & 1 \\
Urethra + rectum & 1 & & \\
Vagina + urethra + rectum & 11 & & \\
Total & 23 & & \\
\hline
\end{tabular}

Table 2 Vaginal carriage $(+)$ of group B streptococci: acquisition or loss at subsequent examination

\begin{tabular}{|c|c|c|c|c|}
\hline & 1st visit & 6 months & 12 months & $\begin{array}{l}\text { No. of } \\
\text { women }\end{array}$ \\
\hline No change & + & + & & 7 \\
\hline No change & - & - & & 4 \\
\hline Gain & - & - & & 8 \\
\hline Loss & + & - & & 4 \\
\hline Loss $\rightarrow$ gain & + & - & + & 2 \\
\hline No follow-up & & & & 4 \\
\hline Total & & & & 29 \\
\hline
\end{tabular}

tered in those who were not vaginal carriers o group B streptococci.

The possibility that group B streptococci coulc cause symptoms was studied in other patients with an IUD who were attending the clinic but were not among the original 100 investigated. Fifty patients without symptoms were swabbed after using an IUD for 12 months. The vaginal carriage rate for group B streptococci was $20 \%$. Thirteen further patients had symptoms suggestive of pelvic inflammatory disease which warranted chemotherapy. Only two were vaginal carriers of group B streptococci, and in each case other likely pathogens were also isolated from the genital tract. An intermediate group of 39

Table 3 Change of serotype of group B streptococci with repeated sampling at various sites

\begin{tabular}{|c|c|c|c|c|c|}
\hline Case No. & Date & Endocervix & Vagina & Urethra & Rectum \\
\hline 1 & $\begin{array}{l}12 \text { March } 1974 \\
\text { 10 Sept. } 1974 \\
21 \text { March } 1975\end{array}$ & $\begin{array}{l}\mathrm{NT}, \mathrm{S} \\
\overline{\mathrm{NT}}, \mathrm{R}\end{array}$ & $\begin{array}{l}\text { NT, } \mathrm{S} \\
\mathrm{NT}, \mathrm{R}\end{array}$ & $\begin{array}{l}\text { NT, S } \\
?, \mathrm{~S} \\
\text { III, R }\end{array}$ & $\begin{array}{l}\text { NT, S } \\
\text { III, R }\end{array}$ \\
\hline 2 & $\begin{array}{r}13 \text { June } 1974 \\
2 \text { July } 1974 \\
11 \text { July } 1974 \\
\text { 3 Feb. } 1975\end{array}$ & $\begin{array}{l}\text { III, S } \\
- \\
-\end{array}$ & $\begin{array}{l}-\overline{\text { III }, S} \\
\text { III, S } \\
-\end{array}$ & $\begin{array}{l}- \\
\overline{I b}, \mathrm{~S}\end{array}$ & $\begin{array}{l}\bar{Z} \\
\mathrm{Ib}, \mathrm{S}\end{array}$ \\
\hline 3 & $\begin{array}{r}19 \text { June } 1974 \\
22 \text { Nov. } 1974 \\
2 \text { April } 1975\end{array}$ & $\overline{\text { III, R }}$ & $\begin{array}{l}\text { Ib, R } \\
\overline{\text { III, }} \mathbf{R}\end{array}$ & Ib, R & III, R \\
\hline 4 & $\begin{array}{l}11 \text { Jan } 1974 \\
26 \text { July } 1974 \\
11 \text { Nov. } 1974\end{array}$ & $\begin{array}{l}\text { Ia, R } \\
\text { NT, R } \\
\text { NT, R }\end{array}$ & $\begin{array}{l}\text { Ia, R } \\
\text { NT, R } \\
\text { NT, R }\end{array}$ & $\begin{array}{l}\text { Ia/NT, R } \\
-\end{array}$ & $\begin{array}{rr}\text { Ia/II, } & \text { R ( } \alpha \text { haemolytic strains) } \\
-\quad & \text { (non-haemolytic strains) } \\
-\quad & \text { (non-haemolytic strains) }\end{array}$ \\
\hline
\end{tabular}

$\mathrm{NT}=$ non-typable. $\mathrm{S}=$ tetracycline sensitive. $\mathrm{R}=$ tetracycline resistant. 
patients had troublesome symptoms thought unlikely to be due to a bacterial cause, such as 'spotting' with blood, prolonged bleeding, discharge, and pain attributable to mechanical factors. The incidence of vaginal carriage in this group was $28 \%$.

\section{Discussion}

The vaginal carriage rate for normal women in this study was $16 \%$ at the first swabbing. If a selective broth enrichment medium had also been employed a slightly higher incidence would almost certainly have been found (Wallin and Forsgren, 1975; Baker et al., 1976; Finch et al., 1976). Whether the small numbers of organisms detected only by fluid culture are likely to persist and ultimately prove to be of clinical significance is perhaps open to question. This incidence is similar to that found in antenatal patients by Baker and Barrett (1973) and in patients in labour by Mhalu (1977). However, in other UK studies Reid (1975) found a vaginal carriage rate of only $4.9 \%$ in pregnant women and Finch et al. (1976) a rate of $6.4 \%$ in women in labour compared with $17 \%$ in non-pregnant women.

Group B streptococci grow fairly well on the acid lactobacillus medium of Rogosa et al. (1951), and it is not clear why vaginal carriage should be reduced in late pregnancy. In the present series vaginal carriage was sometimes transient, even in the absence of chemotherapy, and replacement occurred with a different serotype. Steere et al. (1975) cited evidence that colonisation was stable over a threeto four-month period. Group B streptococci may be sexually acquired (Christensen et al., 1974), but we did not inquire into the possibility of promiscuity in our patients. Bacterial colonisation of the vagina is influenced by the stage of the menstrual cycle (Neary et al., 1973). All women in our study were swabbed in the second week of the cycle after the disappearance of menstrual blood and so were uniformly assessed.

Anorectal swabs showed the highest carriage rate of group B streptococci, $19 \%$. Some strains were probably overlooked because of confluent haemolysis on blood agar plates due to group D streptococci. It is not known whether group B streptococci are confined to the mucocutaneous junction or are true 'enterococci' forming part of the normal faecal flora. The throat carriage rate of $1 \%$ is similar to that found by Jelinková et al. (1970), although Hare (1935) had earlier found a carriage rate of $5 \%$. The urethral carriage rate of $15 \%$ was of the same order as vaginal carriage. However, Wallin and Forsgren (1975), studying group B streptococcal carriage in women attending a venereal disease clinic, found that from the $20 \%$ of carriers $93 \%$ of urethral swabs yielded the organism compared with only $65 \%$ of vaginal swabs.

The high incidence of non-typable strains in nonpregnant women found in our study has been noted previously (Finch et al., 1976; W. R. Maxted, personal communication) but not by some workers (Wilkinson et al., 1973). In a concurrent perinatal survey we had no difficulty in typing most of the group B streptococci isolated from babies and their mothers.

Wallin and Forsgren (1975) concluded that group B streptococci were unrelated to the clinical signs and symptoms of urogenital infections in women such as dysuria, urethral or vaginal discharge, and 'inflammatory mucosal reaction'. Indeed, they showed' that fewer strains were carried by women who showed a leucocytosis in smears of urethral and cervical swabs. In over 200 patients studied over a period of 15 months we found no evidence that group B streptococci were causing genital sepsis in the presence of an IUD. Pathogenicity here cannot readily be evaluated from a Gram-stained smear of exudate since the IUD normally produces an excess of leucocytes by irritant action. A positive blood culture or isolation from the peritoneal cavity would be conclusive but have not so far been encountered by us. Demonstration of a raised titre of antibody to the organism would be invaluable in diagnosis, but such a test is not yet readily available.

At present if group B streptococci are isolated from patients with suspected intrauterine infections. it would seem prudent to treat with penicillin, to which all strains seem to be uniformly moderately sensitive (Finch et al., 1976) but also to considerother possible bacterial pathogens that might require additional chemotherapy.

We are indebted to Dr M. T. Parker, Dr W. R. Maxted, and Mrs C. A. M. Fraser for their helpful advice and for supplying antisera and examining strains.

\section{References}

Baker, C. J., and Barrett, F. F. (1973). Transmission of group B streptococci among parturient women and their neonates. Journal of Pediatrics, 83, 919-925.

Baker, C. J., Goroff, D. K., Alpert, S. L., Hayes, C., and McCormack, W. M. (1976). Comparison of bacteriological methods for the isolation of group B streptococcus from vaginal cultures. Journal of Clinical Microbiology, 4, 46-48.

Braunstein, H., Tucker, E. B., and Gibson, B. C. (1969). Identification and significance of Streptococcus agalactiae (Lancefield Group B.) American Journal of Clinical Pathology, 51, 207-213. 
Butter, M. N. W., and de Moor, C. E. (1967). Streptococcus agalactiae as a cause of meningitis in the newborn, and of bacteraemia in adults. Antonie van Leeuwenhoek, 33, 439-450.

Christensen, K. K., Christensen, P., Flamholc, L., and Ripa, T. (1974). Frequencies of streptococci of groups A, B, C, D and G in urethra and cervix swab specimens with suspected gonococcal infection. Acta Pathologica et Microbiologica Scandinavica, 82B, 470-474.

Eickhoff, T. C., Klein, J. O., Daly, A. K., Ingall, D., and Finland, M. (1964). Neonatal sepsis and other infections due to group B beta-hemolytic streptococci. New England Journal of Medicine, 271, 1221-1228.

Fallon, R. J. (1974). The rapid recognition of Lancefield group B haemolytic streptococci. Journal of Clinical Pathology, 27, 902-905.

Finch, R. G., French, G. L., and Phillips, I. (1976). Group B streptococci in the female genital tract. British Medical Journal, 1, 1245-1247.

Franciosi, R. A., Knostman, J. D., and Zimmerman, R. A. (1973). Group B streptococcal neonatal and infant infections. Journal of Pediatrics, 82, 707-718.

Hare, R. (1935). Classification of haemolytic streptococci from nose and throat of normal human beings by means of precipitin and biochemical tests. Journal of Pathology and Bacteriology, 41, 499-512.

Hood, M., Janney, A., and Dameron, G. (1961). Betahemolytic streptococcus group B associated with problems of the perinatal period. American Journal of Obstetrics and Gynecology, 82, 809-818.

Jelínková, J., Neubauer, M., and Duben, J. (1970). Group B streptococci in human pathology. Zentralblatt für Bakteriologie, Parasitenkunde, Infektionskrankheiten und Hygiene, I Abt. Originale, 214, 450-457.

Mhalu, F. S. (1977). Reservoir of group B streptococci in women in labour. British Medical Journal, 1, 812.

Neary, M. P., Allen, J., Okubadejo, O. A., and Payne, D. J. H. (1973). Preoperative vaginal bacteria and postoperative infections in gynaecological patients. Lancet, 2, 1291-1294.

Reid, T. M. S. (1975). Emergence of group B streptococci in obstetric and perinatal infections. British Medical Journal, 2, 533-535.

Rogosa, M., Mitchell, J. A., and Wiseman, R. F. (1951). A selective medium for the isolation and enumeration of oral and fecal lactobacilli. Journal of Bacteriology, 62, 132-133.

Steere, A. C., Aber, R. C., Warford, L. R., Murphy, K. E., Feeley, J. C., Hayes, P. S., Wilkinson, H. W. and Facklam, R. R. (1975). Possible nosocomial transmission of group B streptococci in a newborn nursery. Journal of Pediatrics, 87, 784-787.

Topley, W. W. C., and Wilson, G. S. (1975). Principles of Bacteriology, Virology and Immunity, 6th edition, edited by Sir Graham S. Wilson and Sir Ashley Miles. Edward Arnold, London.

Wallin, J., and Forsgren, A. (1975). Group B streptococci in venereal disease clinic patients. British Journal of Venereal Diseases, 51, 401-404.

Wilkinson, H. W., Facklam, R. R., and Wortham, E. C. (1973). Distribution by serological type of group B streptococci isolated from a variety of clinical material over a five year period (with special reference to neonatal sepsis and meningitis). Infection and Immunity 8, 228-235. 